\title{
Nitric Oxide Reduction with Hydrogen, Carbon Monoxide, and Hydrocarbons over Gold Catalysts
}

\author{
Atsushi Ueda and Masatake Haruta * \\ Osaka National Research Institute, AIST, Midorigaoka 1-8-31, Ikeda, \\ Osaka 563-8577, Japan
}

Received: 24 February 1999

The reactivity of nitric oxide with reducing gases, using supported gold catalysts is reviewed and assessed in comparison with the use of other precious metal catalysts. Applications for this technology in the purification of exhaust gases are envisaged.

Gold was once thought to be poorly active as a heterogeneous catalyst. However, since we reported that gold shows extraordinarily high catalytic activity for the oxidation of carbon monoxide when it is deposited as nanoparticles on selected metal oxides (1, 2 ), gold has attracted a growing interest from scientists and engineers $(3,4)$.

The catalytic reduction of nitrogen oxides has been one of the most important scientific challenges during the last few decades. The most practical and convenient method for removing nitric oxide (NO) seems to be catalytic reduction using unburnt compounds such as carbon monoxide (CO), hydrogen, and hydrocarbons contained in the exhaust gas. There are two different practical conditions for catalysts to work; ie stoichiometric and lean-burn. Under stoichiometric conditions, where the amount of air supplied is controlled to a level just sufficient for the complete combustion of the fuel, three-way catalysts are used. Only noble metals such as rhodium, palladium, and platinum can be used as catalytic components, due to their durability under both the oxidizing and reducing parts of the cycles. These noble metals are usually supported on oxides with oxygenstorage capacity, such as $\mathrm{CeO}_{2}$ deposited on $\mathrm{Al}_{2} \mathrm{O}_{3}$. On the other hand, diesel engines and lean-burn gasoline engines are operated under lean-burn conditions, where the oxygen is fed in excess, 10 to $20 \%$ more than is required to meet the stoichiometry for combustion of the fuel.
Catalytic reduction of nitrogen oxides ( $\mathrm{NOx}$ ) by hydrocarbons in the presence of excess oxygen is a reasonable target, because a certain amount (100 - 1000 $\mathrm{ppm}$ ) of propene and ethene is usually contained in the exhaust gases of lean-bum gasoline engines and diesel engines (5-7). It has been reported that a variety of metal ion-exchanged zeolites such as Pt-MFI $(8,9)$ and $\mathrm{Cu}_{-}$ MFI $(10,11)$ exhibit good catalytic performances for the reduction of nitric oxide by light alkenes. When natural gas is used as the fuel for gas turbines and lean-burn gas engines, light alkanes rather than alkenes remain as major reducing components in the exhaust gases (12). The reduction of nitric oxide with methane has been attempted over catalysts containing cobalt (13), iridium (14), palladium (15), etc. Ethane and propane have also been studied as reducing agents over $\mathrm{Co}-\beta$-zeolite catalyst (16). Carbon monoxide and hydrogen are also contained in exhaust gases, however, but their contribution to the reduction of $\mathrm{NOx}$ is not well understood.

Supported gold catalysts are surprisingly active for the oxidation of carbon monoxide with oxygen and moderately active for the oxidation of hydrogen by oxygen (2). In this present paper we provide an overview of our recent work on the catalysis of gold for the reduction of nitrogen oxides by carbon monoxide, hydrogen and hydrocarbons, and attempt to compare gold with other transition metals.

*Corresponding author. Tel: (+81)-727-51-9550, Fax: (+81)-727-51-9629, E-mail: haruta@onri.go.jp 


\section{EXPERIMENTAL}

\section{Preparation and Characterization of Gold Catalysts}

The catalytic properties of gold are very dependent on the methods employed for preparation of the catalysts. The method used determines the size and the contact structure of gold particles deposited on the metal oxide supports. Co-precipitation (2) and deposition-precipitation techniques (17) are effective for preparing gold catalysts such as gold supported on oxides containing iron, $\mathrm{Au} / \mathrm{Al}_{2} \mathrm{O}_{3}, \mathrm{Au} / \mathrm{ZnO}$, and $\mathrm{Au} / \mathrm{TiO}_{2}$. One important point in the preparation procedure is that gold tetrachloride anion is transformed into gold hydroxide precursor which is mixed with the hydroxides of the other metals (coprecipitation) or deposited on metal oxide supports (deposition-precipitation).

In this work, gold was deposited on $\mathrm{Al}_{2} \mathrm{O}_{3}, \mathrm{TiO}_{2}$, and $\mathrm{MgO}$ using a deposition-precipitation technique (17). After the $\mathrm{pH}$ of an aqueous solution of chloroauric acid $\left(\mathrm{HAuCl}_{4}\right)$ was adjusted to 7.0 by adding the appropriate quantity of an aqueous $0.1 \mathrm{M}$ sodium hydroxide $(\mathrm{NaOH})$ solution, metal oxide powder was dispersed in the solution under agitation for $1 \mathrm{~h}$ to deposit gold hydroxide $\left(\mathrm{Au}(\mathrm{OH})_{3}\right)$ exclusively on the surface of metal oxide particles. The precursor obtained was washed several times to remove sodium and chloride ions and dried under vacuum for $18 \mathrm{~h}$, and finally calcined in air at $773 \mathrm{~K}$ for 5 h. In the case of the $\mathrm{MgO}$ support, no sodium hydroxide was added, and $\mathrm{Au}(\mathrm{OH})_{3}$ was deposited at $\mathrm{pH} 9-10$ in an aqueous solution of $\mathrm{HAuCl}_{4}$ containing magnesium citrate. Gold supported on $\mathrm{ZnO}$ was prepared by coprecipitation (2) from a mixed aqueous solution of $\mathrm{HAuCl}_{4}$ and $\mathrm{Zn}\left(\mathrm{NO}_{3}\right)_{2}$ followed by similar procedures to those for deposition-precipitation.

Specific surface areas of the catalysts prepared were determined by the BET single point method using a surface area analyzer (Quantasorb Jr). The amount of gold deposited on metal oxides was determined using an inductively coupled plasma spectrometer ICP-AES (Seiko SPS 1200 VR). The X-ray diffraction pattern of each sample before and after the reaction was measured using a Rigaku X-ray powder diffractometer (RINT 2000). The crystallite size of gold was calculated using Scherrer's equation.

\section{Catalytic Activity Measurements}

Catalytic activity was measured using a fixed-bed flow reactor (18). A sample (300 $\mathrm{mg})$ was placed in a quartz tube, heated to $573 \mathrm{~K}$ for $30 \mathrm{~min}$ in a stream of helium at a flow rate of $100 \mathrm{~cm}^{3} \mathrm{~min}^{-1}$, and then kept at $573 \mathrm{~K}$ for $30 \mathrm{~min}$. For nitric oxide reduction with hydrocarbons, the reactant gas mixture containing $\mathrm{NO}$ $1000 \mathrm{ppm}, \mathrm{C}_{3} \mathrm{H}_{6} 1000 \mathrm{ppm}, \mathrm{O}_{2} 5.0$ vol\%, and $\mathrm{H}_{2} \mathrm{O}$ $10.0 \mathrm{vol} \%$ in a helium background was passed through the catalyst bed at a flow rate of $100 \mathrm{~cm}^{3} \mathrm{~min}^{-1}$ unless otherwise stated. The catalyst temperature was raised stepwise and maintained for $2 \mathrm{~h}$ at each temperature. Reactants and products were analysed with a gas chromatograph (Shimadzu GC-14B), and nitric oxide $(\mathrm{NO})$ and nitrogen dioxide $\left(\mathrm{NO}_{2}\right)$ were analysed with a chemiluminescent $\mathrm{NOx}$ meter (Yanaco CLS-88US). Calibration was carried out with a standard gas containing known concentrations of the components.

\section{RESULTS AND DISCUSSION}

\section{Nitric Oxide Reduction by Carbon Monoxide over Supported Gold Catalysts}

Reduction of nitric oxide by carbon monoxide is one of the reactions occurring in catalytic converters for the purification of the engine exhaust gases (Equation 1):

$$
2 \mathrm{NO}+2 \mathrm{CO} \rightarrow \mathrm{N}_{2}+2 \mathrm{CO}_{2}
$$

It is well known that rhodium is the most active amongst all the precious metals for the catalytic conversion of NO by $\mathrm{CO}(19,20)$. Although there are some differences in the literature concerning the relative orders of activity reported for the platinum group metals (21-24), a well-established order is $\mathrm{Rh}>\mathrm{Pd}>\mathrm{Pt}$.

Table 1 shows the experimental results for the NO $+\mathrm{CO}$ reaction in the absence of oxygen over gold supported on several metal oxides. Over $\mathrm{Au}_{\mathrm{u}} / \mathrm{Al}_{2} \mathrm{O}_{3}$, the reaction of $\mathrm{NO}$ with $\mathrm{CO}$ took place even at a temperature as low as $323 \mathrm{~K}$ producing nitrous oxide $\left(\mathrm{N}_{2} \mathrm{O}\right)$ :

$$
2 \mathrm{NO}+\mathrm{CO} \rightarrow \mathrm{N}_{2} \mathrm{O}+\mathrm{CO}_{2}
$$

Over rhodium supported on $\mathrm{Al}_{2} \mathrm{O}_{3}$ the reaction takes place at temperatures above $400 \mathrm{~K}(21,22)$, showing that, in principle, gold catalysts are more active at low temperatures than rhodium catalysts. Harrison et al (25) have proposed that $\mathrm{NO}$ decomposition can make a major kinetic contribution to the $\mathrm{NO}+\mathrm{CO}$ reaction over supported rhodium catalysts. At low temperatures, $\mathrm{N}_{2} \mathrm{O}$ is the principal product and it is only after the reaction temperature is raised to $573 \mathrm{~K}$ that nitrogen formation takes place (26). In contrast, the formation of nitrogen from $\mathrm{NO}$ took place at 373 $\mathrm{K}$ in the presence of $\mathrm{Au} / \mathrm{Al}_{2} \mathrm{O}_{3}$ catalyst.

Among precious metals, the catalytic activity order 
Table 1 Reduction of Nitric Oxide with Carbon Monoxide on Supported Gold Catalysts

\begin{tabular}{|c|c|c|c|c|c|}
\hline \multirow[b]{2}{*}{ Catalyst } & \multicolumn{4}{|c|}{ Conversion of $\mathrm{NO}$ to $\mathrm{N}_{2}$ and $\mathrm{N}_{2} \mathrm{O}(\%)$} & \multirow[b]{2}{*}{$\begin{array}{c}473 \mathrm{~K} \\
\mathrm{~N}_{2}, \mathrm{~N}_{2} \mathrm{O}\end{array}$} \\
\hline & $\begin{array}{c}300 \mathrm{~K} \\
\mathrm{~N}_{2}, \mathrm{~N}_{2} \mathrm{O}\end{array}$ & $\begin{array}{c}323 \mathrm{~K} \\
\mathrm{~N}_{2}, \mathrm{~N}_{2} \mathrm{O}\end{array}$ & $\begin{array}{c}373 \mathrm{~K} \\
\mathrm{~N}_{2}, \mathrm{~N}_{2} \mathrm{O}\end{array}$ & $\begin{array}{c}423 \mathrm{~K} \\
\mathrm{~N}_{2}, \mathrm{~N}_{2} \mathrm{O}\end{array}$ & \\
\hline $\mathrm{Au} / \mathrm{MgO}$ & & $0.0,5.4$ & $8.2,15.2$ & $42.7,0.2$ & $81.5,0.0$ \\
\hline $\mathrm{Au} / \mathrm{Al}_{2} \mathrm{O}_{3}$ & & $0.0,8.9$ & $13.4,24.7$ & $57.2,0.4$ & $92.3,0.0$ \\
\hline $\mathrm{Au} / \mathrm{TiO}_{2}$ & & $0.0,7.2$ & $10.9,18.4$ & $47.6,0.0$ & $85.9,0.0$ \\
\hline $\mathrm{Au} / \alpha-\mathrm{Fe}_{2} \mathrm{O}_{3}$ & $0.0,32.5$ & $0.0,49.5$ & $22.6,51.4$ & $78.0,0.0$ & $100,0.0$ \\
\hline $\mathrm{Au} / \mathrm{ZnO}$ & & $0.0,12.7$ & $18.9,32.7$ & $62.4,0.0$ & $97.4,0.0$ \\
\hline $\mathrm{Au} / \mathrm{MnFe}_{2} \mathrm{O}_{4}$ & $0.0,98.9$ & $0.2,98.5$ & $81.1,4.9$ & $96.5,0.0$ & $100,0.0$ \\
\hline $\mathrm{Au} / \mathrm{CoFe}_{2} \mathrm{O}_{4}$ & $0.0,64.5$ & $0.0,96.1$ & $45.6,32.7$ & $94.3,0.0$ & $100,0.0$ \\
\hline $\mathrm{Au} / \mathrm{NiFe}_{2} \mathrm{O}_{4}$ & $0.0,97.4$ & $0.4,98.2$ & $86.4,12.0$ & $94.0,0.0$ & $100,0.0$ \\
\hline $\mathrm{Au} / \mathrm{ZnFe}_{2} \mathrm{O}_{4}$ & $0.0,84.1$ & $0.0,97.8$ & $83.8,15.4$ & $100,0.0$ & $100,0.0$ \\
\hline $\mathrm{Au} / \mathrm{NiFe}_{2} \mathrm{O}_{4}{ }^{\mathrm{b}}$ & $0.0,82.4$ & $0.0,89.4$ & $92.1,8.2$ & $95.2,0.0$ & $100,0.0$ \\
\hline $\mathrm{Au} / \mathrm{NiFe}_{2} \mathrm{O}_{4} / \mathrm{Al}_{2} \mathrm{O}_{3}{ }^{\mathrm{c}}$ & $0.0,24.7$ & $0.0,39.4$ & $15.5,42.8$ & $62.3,0.2$ & $95.3,0.0$ \\
\hline
\end{tabular}

${ }^{a}$ Reaction gas: 0.1 vol\% CO and 0.1 vol\% $\mathrm{NO}$ in helium at a space velocity of $20,000 \mathrm{~h}^{-1} \mathrm{~cm}^{3} \mathrm{~g}$ catalyst ${ }^{-1}$. The gold loading on metal oxides was 1 wt $\%$. ${ }^{\mathrm{b}}$ Wet conditions, reaction gas: 0.1 vol $\% \mathrm{CO}, 0.1$ vol $\% \mathrm{NO}$ and $1.8 \mathrm{vol} \% \mathrm{H}_{2} \mathrm{O}$ in a helium background at a space velocity of $20,000 \mathrm{~h}^{-1} \mathrm{~cm}^{3} \mathrm{~g} \mathrm{catalyst}^{-1}$.

${ }^{C}$ A bead-shaped catalyst, the loading of gold and $\mathrm{NiFe}_{2} \mathrm{O}_{4}$ on $\mathrm{Al}_{2} \mathrm{O}_{3}$-bead was 0.2 and 2 wt $\%$, respectively.

for the $\mathrm{NO}+\mathrm{CO}$ reaction is consistent with the order of $\mathrm{CO}$ inhibition strength (23). The infrared measurements for $\mathrm{CO}$ adsorption on the surface of gold particles on metal oxides show that $\mathrm{CO}$ inhibition is very weak (27), which could account for the highest catalytic activity for the $\mathrm{NO}+\mathrm{CO}$ reaction with gold catalysts.

The catalytic activity for $\mathrm{NO}$ reduction by $\mathrm{CO}$ over supported gold catalysts changes drastically depending on the kind of metal oxide supports employed. It is especially noteworthy that oxides containing iron provide the highest catalytic activity for the $\mathrm{NO}+\mathrm{CO}$ reaction. Over $\mathrm{Au} / \mathrm{NiFe}_{2} \mathrm{O}_{4}$, the reduction of $\mathrm{NO}$ by $\mathrm{CO}$ took place even at $300 \mathrm{~K}$ to form $\mathrm{N}_{2} \mathrm{O}$, and at $373 \mathrm{~K}$ most of the $\mathrm{NO}$ was reduced to nitrogen. This extraordinarily high activity of gold catalysts can be maintained in the presence of moisture (Table 1). These results show that gold catalysts are superior in their low-temperature catalytic activity to Rh-modified (28), Pt-modified (29) and Pd-modified catalysts $(30,31)$.

For the application to lean-burn exhaust gases, the $\mathrm{NO}+\mathrm{CO}$ reaction in the presence of oxygen is of more practical importance, especially at lower temperatures. Figure 1 compares $\mathrm{NO}$ reduction by $\mathrm{CO}$ (1 vol\%) over $\mathrm{Au}_{4} / \mathrm{Al}_{2} \mathrm{O}_{3}$ with that for a mechanical mixture of $\mathrm{Mn}_{2} \mathrm{O}_{3}$ with $\mathrm{Au}_{1} / \mathrm{Al}_{2} \mathrm{O}_{3}$ in the presence of a high concentration oxygen ( $5 \mathrm{vol} \%$ ). Over $\mathrm{Au} / \mathrm{Al}_{2} \mathrm{O}_{3}$, the $\mathrm{NO}+\mathrm{CO}$ reaction was strongly inhibited by the presence of oxygen, giving a maximum conversion of $\mathrm{NO}$ to $\mathrm{N}_{2}$, of $5 \%$. The $\mathrm{O}_{2}+$ $\mathrm{CO}$ reaction takes place in preference to the $\mathrm{NO}+$ $\mathrm{CO}$ reaction. On the other hand, the mechanical mixture of $\mathrm{Mn}_{2} \mathrm{O}_{3}$ with $\mathrm{Au} / \mathrm{Al}_{2} \mathrm{O}_{3}$ gave a higher $\mathrm{NO}$ conversion to $\mathrm{N}_{2}(21 \%)$ at $623 \mathrm{~K}$. It is likely that $\mathrm{Mn}_{2} \mathrm{O}_{3}$ catalyses the reaction of $\mathrm{NO}$ with $\mathrm{O}_{2}$ to form nitrogen dioxide $\left(\mathrm{NO}_{2}\right)$, which then reacts with $\mathrm{CO}$ adsorbed on the surface of gold particles supported on $\mathrm{Al}_{2} \mathrm{O}_{3}$ (Equation 3):

$$
2 \mathrm{NO}_{2}+4 \mathrm{CO} \rightarrow \mathrm{N}_{2}+4 \mathrm{CO}_{2}
$$

\section{Reduction of Nitric Oxide by Hydrogen over Supported Gold Catalysts}

Hydrogen is also present in the exhaust gases from combustion of hydrocarbons because it can be generated either by the water gas shift reaction (Equation 4) or the steam reforming reaction ( $\mathrm{g} g$ Equation 5):

$$
\begin{gathered}
\mathrm{CO}+\mathrm{H}_{2} \mathrm{O} \rightarrow \mathrm{CO}_{2}+\mathrm{H}_{2} \\
\mathrm{C}_{3} \mathrm{H}_{8}+6 \mathrm{H}_{2} \mathrm{O} \rightarrow 3 \mathrm{CO}_{2}+10 \mathrm{H}_{2}
\end{gathered}
$$




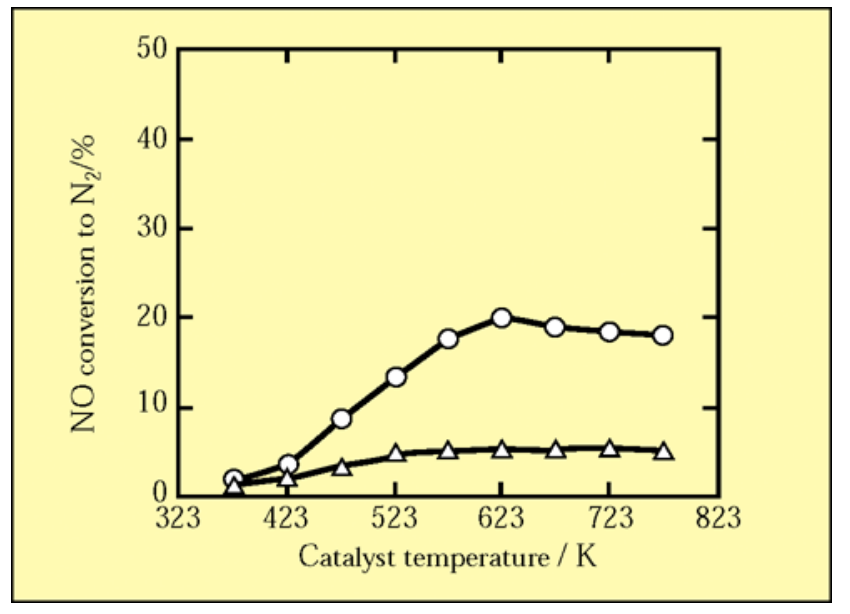

Figure $1 \mathrm{NO}$ conversion to $\mathrm{N}_{2}$ as a function of catalyst temperature over $\mathrm{Au} / \mathrm{Al}_{2} \mathrm{O}_{3}+\mathrm{Mn}_{2} \mathrm{O}_{3}$ and $\mathrm{Au} / \mathrm{Al}_{2} \mathrm{O}_{3}$ in the $\mathrm{NO}+\mathrm{CO}+\mathrm{O}_{2}$ reaction. $(\mathrm{O})$, $\mathrm{Au}(0.17 \mathrm{Wt} \%) / \mathrm{Al}_{2} \mathrm{O}_{3}+\mathrm{Mn}_{2} \mathrm{O}_{3}$ (19:1 in weight), ( $\triangle$ ), $\mathrm{Au}(0.17 \mathrm{wt} \%) \mathrm{Al}_{2} \mathrm{O}_{3}$. Reaction gas: 0.1 vol\% $\mathrm{NO}, 0.1 \mathrm{vol} \% \mathrm{CO}$, and $5.0 \mathrm{vol} \% \mathrm{O}_{2}$ in a helium background at a space velocity of $20,000 \mathrm{~h}^{-1} \mathrm{~cm}^{3}$ $g_{\text {- }}$ catalyst $^{-I}$.

Table 2 lists the results for the reduction of $\mathrm{NO}$ by $\mathrm{H}_{2}$ over $\mathrm{Au}, \mathrm{Pd}, \mathrm{Pt}, \mathrm{Rh}, \mathrm{Ru}$, and Ir catalysts in the presence of oxygen. The relative catalytic activity sequence is $\mathrm{Pt}>\mathrm{Rh}>\mathrm{Pd}>\mathrm{Au}, \mathrm{Ru}>\mathrm{Ir}$. Taylor (21) proposed that the reaction paths for $\mathrm{NO}$ reduction by hydrogen over $\mathrm{Pd}$ and $\mathrm{Pt}$ supported on $\mathrm{Al}_{2} \mathrm{O}_{3}$ are $\mathrm{NO}$ decomposition over the metals followed by the removal of adsorbed oxygen species by $\mathrm{H}_{2}$ (Equation 6):

$$
2 \mathrm{NO} \rightarrow \underset{\text { ads }}{\mathrm{N}_{2}}+\underset{\mathrm{O}_{2}}{\stackrel{\mathrm{H}_{2}}{\rightarrow}} \mathrm{H}_{2} \mathrm{O}
$$

The above order for $\mathrm{NO}$ reduction by $\mathrm{H}_{2}$ can be explained by the fact that gold gives the middle activity amongst the precious metals for both NO decomposition and the $\mathrm{O}_{2}+\mathrm{H}_{2}$ reaction. Over $\mathrm{Pd} / \mathrm{TiO}_{2}$, the two conversion maxima for $\mathrm{NO}$ reduction by hydrogen appear at temperatures of $400 \mathrm{~K}$ and $600 \mathrm{~K}$, and this is closely related to $\mathrm{NO}$ oxidation to $\mathrm{NO}_{2}$ (32). The combination of $\mathrm{NO}$ oxidation by oxygen and $\mathrm{NO}_{2}$ reduction by hydrogen may also give further improvement of $\mathrm{NOx}$ conversion to $\mathrm{N}_{2}$ as was the case with the $\mathrm{NO}+\mathrm{CO}+\mathrm{O}_{2}$ reaction.

\section{Reduction of Nitric Oxide by Hydrocarbons over Supported Gold Catalysts}

\section{Support Effect of Metal Oxides}

Table 3 shows that the temperature range at which the reduction of $\mathrm{NO}$ to $\mathrm{N}_{2}$ by propene takes place varies with the type of metal oxide support used for gold. Gold supported on $\mathrm{ZnO}, \alpha-\mathrm{Fe}_{2} \mathrm{O}_{3}$ and $\mathrm{ZrO}_{2}$ is active at lower temperatures. This is especially notable at $523 \mathrm{~K}$, where the $\mathrm{Au} / \mathrm{ZnO}$ catalyst gives a maximum of $49 \%$ in the conversion to $\mathrm{N}_{2}$ and, in addition, $16 \%$ conversion to $\mathrm{N}_{2} \mathrm{O}$ (Equation 7):

Table 2 Reduction of Nitric Oxide with Hydrogen over Supported Precious Metals Catalysts

\begin{tabular}{|c|c|c|c|c|c|}
\hline \multirow[b]{2}{*}{ Catalyst } & \multicolumn{4}{|c|}{ Conversion of $\mathrm{NO}$ to $\mathrm{N}_{2}$ and $\mathrm{N}_{2} \mathrm{O}(\%)$} & \multirow[b]{2}{*}{$\begin{array}{c}623 \mathrm{~K} \\
\mathrm{~N}_{2}, \mathrm{~N}_{2} \mathrm{O}\end{array}$} \\
\hline & $\begin{array}{c}323 \mathrm{~K} \\
\mathrm{~N}_{2}, \mathrm{~N}_{2} \mathrm{O}\end{array}$ & $\begin{array}{c}373 \mathrm{~K} \\
\mathrm{~N}_{2}, \mathrm{~N}_{2} \mathrm{O}\end{array}$ & $\begin{array}{c}473 \mathrm{~K} \\
\mathrm{~N}_{2}, \mathrm{~N}_{2} \mathrm{O}\end{array}$ & $\begin{array}{c}573 \mathrm{~K} \\
\mathrm{~N}_{2}, \mathrm{~N}_{2} \mathrm{O}\end{array}$ & \\
\hline $\mathrm{Ru} / \mathrm{Al}_{2} \mathrm{O}_{3}$ & $0.0,0.0$ & $5.2,3.2$ & $27.3,5.8$ & $7.9,0.0$ & $1.2,0.0$ \\
\hline $\mathrm{Rh} / \mathrm{Al}_{2} \mathrm{O}_{3}$ & $0.2,1.5$ & $5.4,34.5$ & $0.5,0.0$ & $0.5,0.0$ & $0.2,0.0$ \\
\hline $\mathrm{Pd} / \mathrm{Al}_{2} \mathrm{O}_{3}$ & $0.0,0.8$ & $2.7,0.0$ & $1.2,0.0$ & $2.1,0.0$ & $1.2,0.0$ \\
\hline $\mathrm{Pd} / \mathrm{TiO}_{2}$ & $2.8,6.8$ & $21.7,25.8$ & $2.8,2.6$ & $27.4,17.5$ & $24.4,15.7$ \\
\hline $\mathrm{Ir} / \mathrm{Al}_{2} \mathrm{O}_{3}$ & $0.0,0.0$ & $6.4,2.8$ & $32.4,0.2$ & $12.4,0.0$ & $7.9,0.0$ \\
\hline $\mathrm{Pt} / \mathrm{Al}_{2} \mathrm{O}_{3}$ & $0.4,4.4$ & $6.6,55.6$ & $0.2,0.0$ & $2.8,0.0$ & $0.2,0.0$ \\
\hline $\mathrm{Pt} / \mathrm{TiO}_{2}$ & $1.5,5.8$ & $10.5,40.1$ & $0.4,0.2$ & $0.6,0.0$ & $0.2,0.0$ \\
\hline $\mathrm{Au} / \mathrm{Al}_{2} \mathrm{O}_{3}$ & $0.0,0.0$ & $6.4,2.8$ & $32.4,0.2$ & $12.4,0.0$ & $7.9,0.0$ \\
\hline $\mathrm{Au} / \mathrm{TiO}_{2}$ & $0.0,0.0$ & $7.8,1.5$ & $34.3,0.0$ & $10.7,0.0$ & $4.2,0.0$ \\
\hline
\end{tabular}

${ }^{a}$ Reaction gas: 0.1 vol\% NO, 0.3 vol\% $\mathrm{H}_{2}, 5.0$ vol\% $\mathrm{O}_{2}$, and 10.0 vol\% $\mathrm{H}_{2} \mathrm{O}$ in helium, at a space velocity of $20,000 \mathrm{~h}^{-1} \mathrm{~cm}^{3} \mathrm{~g} \mathrm{catalyst}^{-1}$. The loading of precious metal on metal oxides was $1 \mathrm{wt} \%$. 
Table 3 Metal Loadings, Mean Diameters of Gold Particles, and Specific Surface Areas of the Tested Catalysts, and NO Conversion to $\mathrm{N}_{2}$ and $\mathrm{N}_{2} \mathrm{O}$ over Several Gold Catalysts and Metal Oxides

\begin{tabular}{|c|c|c|c|c|c|c|c|c|c|c|c|}
\hline \multirow[t]{2}{*}{ Catalyst } & \multirow{2}{*}{$\begin{array}{c}\text { Preparation } \\
\text { method }^{\mathrm{a}}\end{array}$} & \multirow{2}{*}{$\begin{array}{c}\text { Au loading }{ }^{\mathrm{b}} \\
\text { (wt. } \%)\end{array}$} & \multirow{2}{*}{$\begin{array}{l}\mathrm{d}_{\mathrm{Au}}{ }^{\mathrm{c}} \\
(\mathrm{nm})\end{array}$} & \multirow{2}{*}{$\begin{array}{l}\text { Surface area } \\
\qquad\left(\mathrm{m}^{2} \mathrm{~g}^{-1}\right)\end{array}$} & \multicolumn{7}{|c|}{$\mathrm{NO}$ conversion to $\mathrm{N}_{2}(\%)^{d}$} \\
\hline & & & & & $473 K$ & $523 \mathrm{~K}$ & $573 \mathrm{~K}$ & $623 \mathrm{~K}$ & $673 \mathrm{~K}$ & $723 \mathrm{~K}$ & $773 \mathrm{~K}$ \\
\hline $\mathrm{Au} / \mathrm{MgO}$ & $\mathrm{DP}$ & 0.85 & 5.1 & 166 & 8.6 & 12.6 & 20.2 & 42.5 & 37.7 & & \\
\hline $\mathrm{Au} / \mathrm{Al}_{2} \mathrm{O}_{3}$ & DP & 0.17 & - & 172 & 3.8 & 12.3 & 30.8 & 50.9 & 80.7 & 80.5 & 61.6 \\
\hline $\mathrm{Au} / \mathrm{Al}_{2} \mathrm{O}_{3}$ & DP & 0.28 & 4.9 & 173 & 4.2 & 6.8 & 12.2 & 34.1 & 50.7 & 39.4 & \\
\hline $\mathrm{Au} / \mathrm{Al}_{2} \mathrm{O}_{3}$ & IMP & 1.1 & 32.0 & 174 & & & 0.1 & 18.2 & 15.5 & 10.3 & \\
\hline $\mathrm{Au} / \mathrm{TiO}_{2}$ & DP & 0.76 & 3.3 & 39 & 5.5 & 8.1 & 18.4 & 30.4 & 18.9 & & \\
\hline $\mathrm{Au} / \alpha-\mathrm{Fe}_{2} \mathrm{O}_{3}$ & DP & 0.79 & 3.4 & 23 & 6.1 & 12.3 & 7.8 & 3.1 & 1.7 & & \\
\hline $\mathrm{Au} / \mathrm{ZnO}$ & $\mathrm{CP}$ & 1.2 & 3.5 & 36 & 24.4 & 49.2 & 35.1 & 23.5 & 14.0 & & \\
\hline $\mathrm{Au} / \mathrm{ZrO}_{2}$ & DP & 0.84 & 3.8 & 24 & 12.3 & 32.4 & 24.5 & 17.4 & 8.2 & & \\
\hline $\mathrm{Al}_{2} \mathrm{O}_{3}$ & - & - & & 174 & & & & 0.5 & 1.2 & 1.8 & 2.6 \\
\hline
\end{tabular}

a DP; deposition-precipitation, IMP; impregnation, CP; co-precipitation. ${ }^{\mathrm{b}}$ Gold loading was determined by inductively coupled plasma spectrometry (ICP-AES). ${ }^{c}$ Crystallite size of gold was calculated by using Scherrer's equation from XRD data. ${ }^{\mathrm{d}} \mathrm{NO}$ reduction by propene, reaction condition; 0.1 vol\% NO, 0.1 vol\% $\mathrm{C}_{3} \mathrm{H}_{6}, 5.0$ vol\% $\mathrm{O}_{2}$, and 10.0 vol\% $\mathrm{H}_{2} \mathrm{O}$ in $\mathrm{He}$, Space Velocity $=20,000 \mathrm{~h}^{-1} \mathrm{~cm}^{3} \mathrm{~g}$-catalyst ${ }^{1}$.

$$
\mathrm{NO} \stackrel{\mathrm{O}_{2}}{\rightarrow} \mathrm{NO}_{2} \stackrel{\mathrm{C}_{3} \mathrm{H}_{6}}{\rightarrow} \mathrm{N}_{2}
$$

Gold supported on $\mathrm{MgO}$ and $\mathrm{TiO}_{2}$ gives the middletemperature conversion of $\mathrm{NO}$. Gold (1wt\%) on $\mathrm{Al}_{2} \mathrm{O}_{3}$ can provide appreciably higher conversion to $\mathrm{N}_{2}$ with a maximum of $51 \%$ at $673 \mathrm{~K}$ and at this temperature the formation of $\mathrm{N}_{2} \mathrm{O}$ was no longer observed. Because the minimum detectable concentration of $\mathrm{N}_{2} \mathrm{O}$ was 10 ppm using our analytical instrumentation, the above result showed that $\mathrm{NO}$ conversion to $\mathrm{N}_{2} \mathrm{O}$ was less than $2 \%$. In contrast, $\mathrm{Au}_{\mathrm{Al}} \mathrm{O}_{3}$ prepared by impregnation, which contains gold particles much larger than those obtained for deposition-precipitation, is much less active for NO reduction by propene. As is the case for $\mathrm{CO}$ oxidation (33), the preparation method used for gold catalysts is also very important in $\mathrm{NO}$ reduction and the size of the gold particles is one of the controlling factors for catalytic activity (34). The lower content of gold $(0.2 \mathrm{wt} \%)$ on $\mathrm{Al}_{2} \mathrm{O}_{3}$ gives much higher $\mathrm{NO}$ conversion to $\mathrm{N}_{2}(80 \%)$, although it requires the relatively higher reaction temperature of $723 \mathrm{~K}$.

In comparison with the above gold catalysts, platinum and palladium supported on metal oxides exhibit activities at lower temperatures but the propene and oxygen compete to a greater extent, resulting in lower maximum conversions to $\mathrm{N}_{2}(35,36)$.

\section{$\mathrm{Au} / \mathrm{Al}_{2} \mathrm{O}_{3}$ Catalysts}

Since gold supported on alumina gives the highest maximum conversion to nitrogen, its catalytic behaviour for $\mathrm{NO}$ reduction has been studied in greater detail.

\section{Effect of Moisture in the Reactants}

Comparison of the effect of moisture on NO reduction with propene is remarkably different for $\mathrm{Au} / \mathrm{Al}_{2} \mathrm{O}_{3}$ and $\mathrm{Al}_{2} \mathrm{O}_{3}$ (Figure 2). Although the conversion to $\mathrm{N}_{2}$ over $\mathrm{Al}_{2} \mathrm{O}_{3}$ markedly decreased with increasing concentration of water, over $\mathrm{Au} / \mathrm{Al}_{2} \mathrm{O}_{3}$ an increase in water concentration gave rise to small increases in the conversion to nitrogen. The enhancing effect of moisture has also been observed in $\mathrm{CO}$ oxidation over other supported gold catalysts (37) and provides gold catalysts with a significant potential advantage in applications for combustion of exhaust gases, since these usually contain water at a concentration higher than $10 \mathrm{vol} \%$. The catalysts which contain the oxides of base transition metals such as $\mathrm{Cu}, \mathrm{Ag}$, and $\mathrm{Co}$, as catalytically active species were appreciably deactivated by moisture $(12,38$, $39)$. In the case of Pt supported on metal oxides, NO conversion is maintained even in the presence of high concentrations of water, but this is accompanied by enhanced formation of $\mathrm{N}_{2} \mathrm{O}(36,40,41)$.

\section{Effect of Oxygen in the Reactants}

Figure 3 indicates that $\mathrm{NO}$ conversion is very low $(8.4 \%)$ in the absence of oxygen, and that the addition of oxygen in the reactant stream appreciably enhances the reduction of NO up to a conversion of $69 \%$ (at an oxygen concentration of $4 \mathrm{vol} \%$ ). The conversion to 


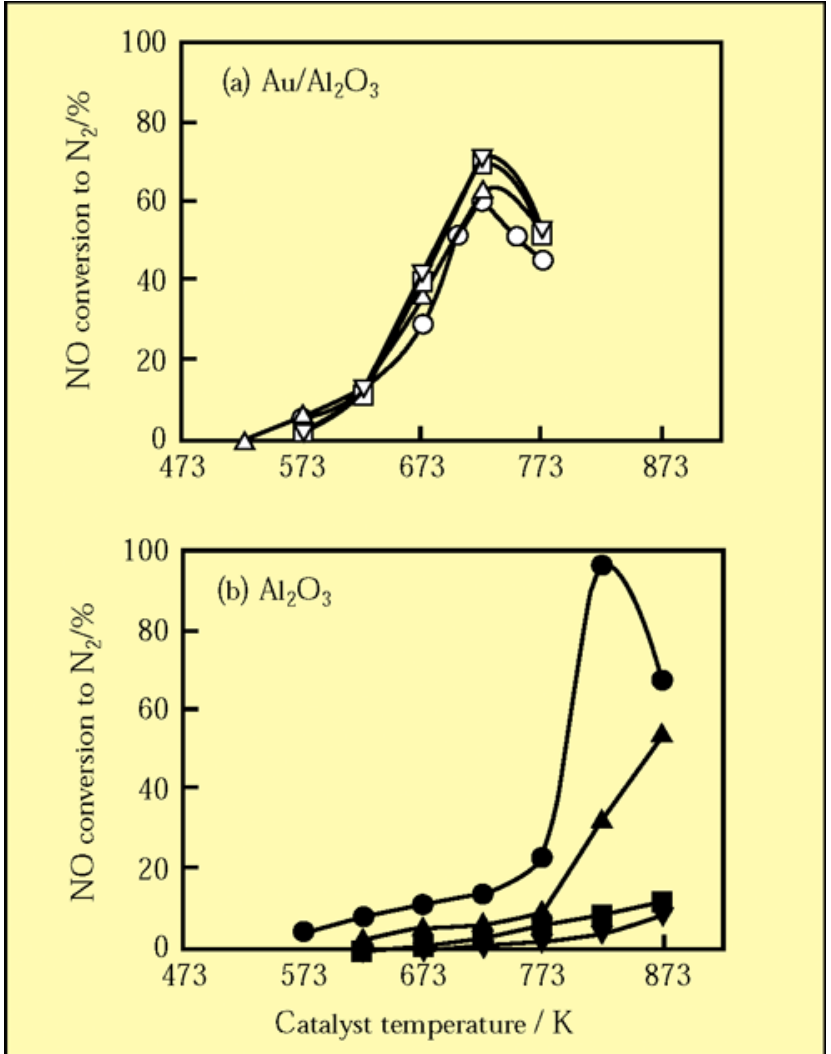

Figure $2 \mathrm{NO}$ reduction to $\mathrm{N}_{2}$ as a function of catalyst temperature over (a) $\mathrm{Au}_{\mathrm{Al}} \mathrm{O}_{3}$ and (b) $\mathrm{Al}_{2} \mathrm{O}_{3}$ under different concentrations of $\mathrm{H}_{2} \mathrm{O},(\mathrm{O}, \triangle, \square, \nabla)$, $\mathrm{Au}\left(0.17\right.$ wt. \%) $/ \mathrm{Al}_{2} \mathrm{O}_{3} ;(\mathbf{O}, \mathbf{\Lambda}, \mathbf{\square}, \mathbf{\nabla}), \mathrm{Al}_{2} \mathrm{O}_{3}$; $(\mathrm{O}, \mathbf{O}), \mathrm{dry} ;(\triangle, \mathbf{\Delta}), \mathrm{H}_{2} \mathrm{O}=1.8 \mathrm{vol} \% ;(\square, \mathbf{\square})$, $\mathrm{H}_{2} \mathrm{O}=5.1$ vol\%; $(\nabla, \nabla), \mathrm{H}_{2} \mathrm{O}=9.8 \mathrm{vol} \%$. Reaction gas. 0.1 vol\% NO, 0.1 vol. $\% \mathrm{C}_{3} \mathrm{H}_{6}, 5.0$ vol\% $\mathrm{O}_{2}$, and $\mathrm{H}_{2} \mathrm{O}$ in a helium background at a space velocity of $20,000 \mathrm{~h}^{-1} \mathrm{~cm}^{3} \mathrm{~g}$-catalyst ${ }^{-1}$

$\mathrm{N}_{2}$ remained almost constant in the oxygen concentration range of 6 to $20 \mathrm{vol} \%$. This shows that oxygen is indispensable for the reduction of $\mathrm{NO}$ by propene. The steady conversion of $\mathrm{NO}$ on $\mathrm{Au} / \mathrm{Al}_{2} \mathrm{O}_{3}$ catalysts at high oxygen concentration range is advantageous for applications with exhaust gases under lean burn conditions, which usually contain oxygen at a concentration from 1 to $15 \mathrm{vol} \%$.

Figure 4 shows the effects of $\mathrm{CO}$ addition on $\mathrm{NO}$ reduction by propene over $\mathrm{Au}_{\mathrm{u}} / \mathrm{Al}_{2} \mathrm{O}_{3}$. The $\mathrm{CO}$ addition gave a positive effect of higher yields of $\mathrm{N}_{2}$ $(60 \rightarrow 75 \%$, at $673 \mathrm{~K})$.

Reaction Pathways in the Reduction of Nitric Oxide by Hydrocarbons

Since oxygen appreciably enhances the reduction of

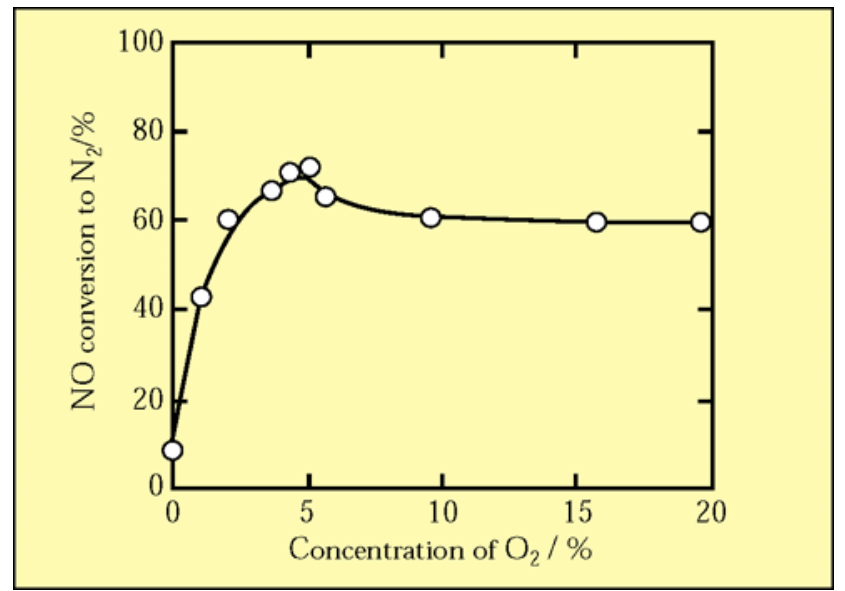

Figure $3 \mathrm{NO}$ conversion to $\mathrm{N}_{2}$ as a function of the concentration of oxygen over $\mathrm{Au}(0.17 \mathrm{wt} \%) / \mathrm{Al}_{2} \mathrm{O}_{3}$ at $723 \mathrm{~K}$. Reaction gas: 0.1 vol\% $\mathrm{NO}, 0.1$ vol\% $\mathrm{C}_{3} \mathrm{H}_{6}$ 5.1 vol\% $\mathrm{H}_{2} \mathrm{O}$, and $\mathrm{O}_{2}$ in a helium background at a space velocity of $20,000 \mathrm{~h}^{-1} \mathrm{~cm}^{3}$ g-catalyst $^{-1}$

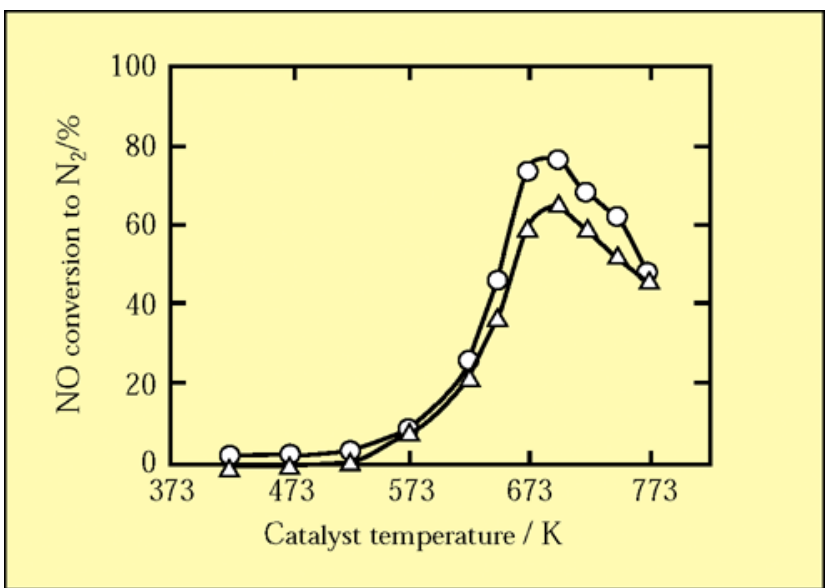

Figure 4 Effect of the CO addition into NO reduction by propene over $\mathrm{Au}\left(1_{\mathrm{wt}} \%\right) / \mathrm{Al}_{2} \mathrm{O}_{3}$. (O), $987 \mathrm{ppm} \mathrm{NO}$, $750 \mathrm{ppm} \mathrm{C}_{3} \mathrm{H}_{6}, 987 \mathrm{ppm} \mathrm{CO}, 4.9$ vol\% $\mathrm{O}_{2}$, and $5.1 \mathrm{vol} \% \mathrm{H}_{2} \mathrm{O}$ in a He background; ( $\triangle$ ) $987 \mathrm{ppm}$ $\mathrm{NO}, 750 \mathrm{ppm} \mathrm{C}_{3} \mathrm{H}_{6}, 4.9$ vol\% $\mathrm{O}_{2}$, and 5.1 vol\% $\mathrm{H}_{2} \mathrm{O}$ in a helium background. Space velocity was $20,000 \mathrm{~h}^{-1} \mathrm{~cm}^{3}$ g-catalyst $^{-1}$

$\mathrm{NO}$ by hydrocarbons, it is likely that the oxidation of $\mathrm{NO}$ by oxygen $\left(2 \mathrm{NO}+\mathrm{O}_{2} \rightarrow 2 \mathrm{NO}_{2}\right.$ ) takes place first, and then $\mathrm{NO}_{2}$ is reduced by hydrocarbons to $\mathrm{N}_{2}$ $(34,42,43)$. As shown in Figure 5 , the reaction of $\mathrm{NO}$ with molecular oxygen to form $\mathrm{NO}_{2}$ takes place over $\mathrm{Au} / \mathrm{Al}_{2} \mathrm{O}_{3}$ at temperatures above $573 \mathrm{~K}$, just where the reduction of $\mathrm{NO}$ by propene starts (Figure 2 ), and the conversion to $\mathrm{NO}_{2}$ reaches almost the equilibrium value at $723 \mathrm{~K}$. In addition, moisture in the reactant 


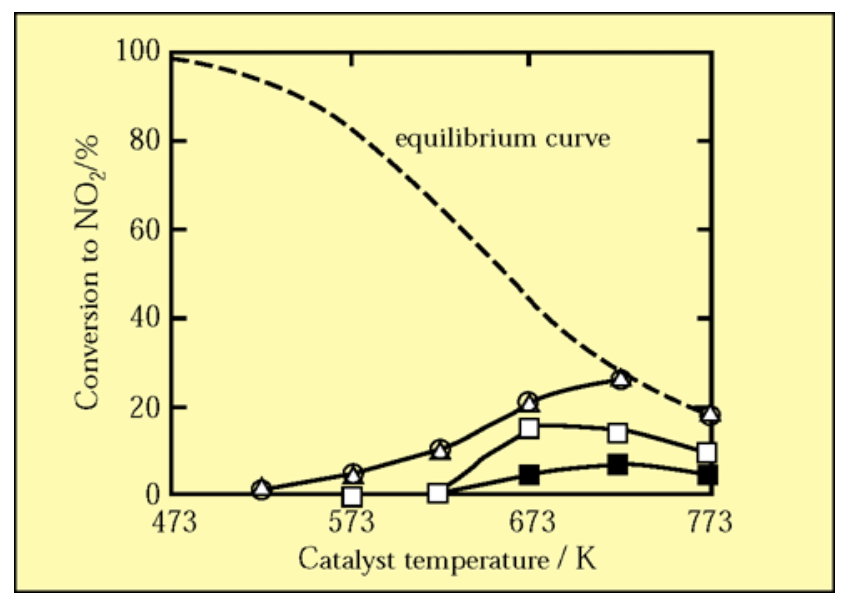

Figure 5 Conversion in $N O$ oxidation as a function of catalyst temperature. (O, $\triangle$ ), $\mathrm{Au}\left(\mathrm{l}_{w} \mathrm{w} \%\right) / \mathrm{Al}_{2} \mathrm{O}_{3}:(\square, \mathbf{\square})$, $\mathrm{Al}_{2} \mathrm{O}_{3} \cdot(\mathrm{O}, \square), 0.1$ vol\% $\mathrm{NO}$ and $5.0 \mathrm{vol} \% \mathrm{O}_{2}$ in a helium background; $(\triangle, \square), 0.1$ vol\% NO, 5.0 vol\% $\mathrm{O}_{2}$, and 5.1 vol\% $\mathrm{H}_{2} \mathrm{O}$ in a helium background. Space velocity was $20,000 \mathrm{~h}^{-1} \mathrm{~cm}^{3} \mathrm{~g}$ catalyst $^{-1}$

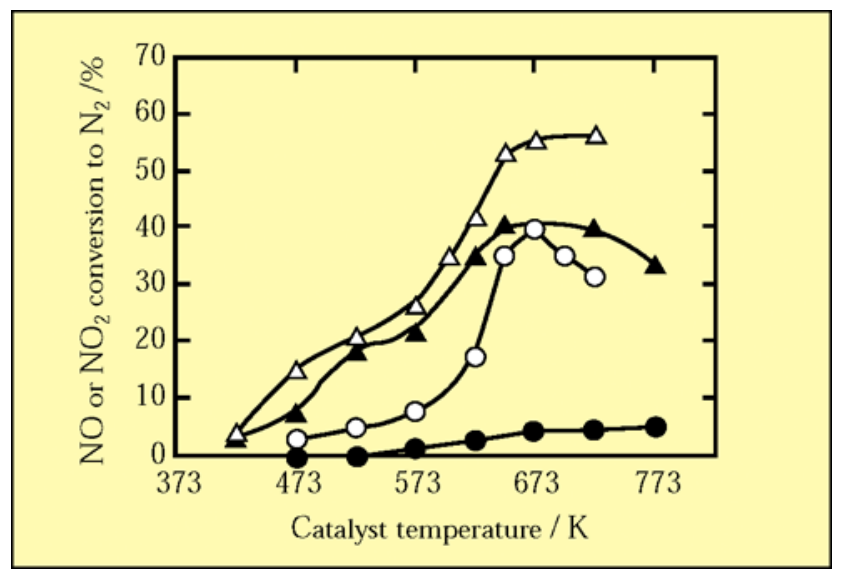

Figure 6 Effect of oxygen on the reduction of $\mathrm{NO}$ and $\mathrm{NO}_{2}$ with propene over $\mathrm{Au}(1 \mathrm{wt} \%) / \mathrm{Al}_{2} \mathrm{O}_{3} .(\mathrm{O}), 0.1$ vol\% $\mathrm{NO}, 0.05 \mathrm{vol} \% \mathrm{C}_{3} \mathrm{H}_{6}, 5.0 \mathrm{vol} \% \mathrm{O}_{2}$, and $5.1 \mathrm{vol} \%$ $\mathrm{H}_{2} \mathrm{O}$ in a helium background; (O), 0.1 vol\% $\mathrm{NO}$. 0.05 vol\% $\mathrm{C}_{3} \mathrm{H}_{6}$, and 5.1 vol\% $\mathrm{H}_{2} \mathrm{O}$ in a helium background; ( $\mathbf{\Delta}), 0.1$ vol\% $\mathrm{NO}_{2}, 0.05$ vol\% $\mathrm{C}_{3} \mathrm{H}_{6}$. 5.0 vol\% $\mathrm{O}_{2}$, and 5.1 vol\% $\mathrm{H}_{2} \mathrm{O}$ in a helium background; ( $\triangle$ ), 0.1 vol\% $\mathrm{NO}_{2}, 0.05 \mathrm{vol} \% \mathrm{C}_{3} \mathrm{H}_{6}$, and 5.1 vol\% $\mathrm{H}_{2} \mathrm{O}$ in a helium background. Space velocity $=20,000 \mathrm{~h}^{-1} \mathrm{~cm}^{3} \mathrm{~g}_{\text {-catalyst }}{ }^{-1}$

stream does not depress the oxidation of $\mathrm{NO}$ with $\mathrm{O}_{2}$. The reduction of $\mathrm{NO}_{2}$ to $\mathrm{N}_{2}$ by propene always takes place at lower temperatures than $\mathrm{NO}$ reduction, yielding higher conversions to $\mathrm{N}_{2}$ (Figure 6), and proceeds even in the absence of oxygen. These results indicate that the reactivity of $\mathrm{NO}_{2}$ with propene is much larger than that of $\mathrm{NO}$. Accordingly, the reduction of $\mathrm{NO}$ to $\mathrm{N}_{2}$ over $\mathrm{Au} / \mathrm{Al}_{2} \mathrm{O}_{3}$ catalysts can be assumed to take place via the formation of $\mathrm{NO}_{2}$ by the oxidation of $\mathrm{NO}$ with oxygen as the first and slowest step and the subsequent reduction of $\mathrm{NO}_{2}$ by propene. Since nitric oxide reacts with propene in a molar ratio of almost unity and the conversion of $\mathrm{NO}$ reaches about $70 \%$ on $\mathrm{Au} / \mathrm{Al}_{2} \mathrm{O}_{3}$, propene may be oxidized first by $\mathrm{NO}_{2}$ and then the subsequent oxidation of propene oxygenates taking place mainly with oxygen (34). This feature is one of the greatest constraints of supported gold catalysts, because it results in relatively low selectivity of hydrocarbons to $\mathrm{NO}$ reduction, compared with that of $\mathrm{Cu}-\mathrm{MFI}$ catalysts (36).

Burch et al $(44,45)$ have proposed that $\mathrm{NO}$ decomposition, which produces adsorbed oxygen and nitrogen atoms, plays a major role in the reduction of $\mathrm{NO}$ by hydrocarbons over $\mathrm{Pt}$ supported on metal oxides. The reaction between the adsorbed oxygen atoms and hydrocarbons from the gas phase takes place on the surface of platinum particles supported on metal oxide. The relatively higher selectivity to $\mathrm{N}_{2} \mathrm{O}$ over $\mathrm{Pt}$ on metal oxides can be explained by the formation of $\mathrm{N}_{2} \mathrm{O}$ from $\mathrm{NO}$ and dissociated nitrogen atoms adsorbed on platinum particles.

\section{Effect of Addition of $\mathrm{Mn}_{2} \mathrm{O}_{3}$ to $\mathrm{Au}_{\mathbf{u}} / \mathrm{Al}_{2} \mathrm{O}_{3}$ Catalysts}

Since the oxidation of $\mathrm{NO}$ to $\mathrm{NO}_{2}$ appears to be a ratedetermining step in $\mathrm{NO}$ reduction, acceleration of this reaction would mean that $\mathrm{NO}$ reduction would take place at lower temperatures. Based on this hypothesis, $\mathrm{Mn}_{2} \mathrm{O}_{3}$ which is the most active catalyst for the oxidation of $\mathrm{NO}$ to $\mathrm{NO}_{2}$ and less active for hydrocarbon oxidation with oxygen has been combined with $\mathrm{Au}_{1} / \mathrm{Al}_{2} \mathrm{O}_{3}$ through mechanical mixing (18). As shown in Figure 7, this combination can maintain high conversion from lower to higher temperatures and offers one of the best catalytic performances in $\mathrm{NO}$ conversion among the catalysts so far reported. This bifunctional mechanism, composed of $\mathrm{NO}$ oxidation and $\mathrm{NO}_{2}$ reduction by hydrocarbons has been proposed and reviewed by Misono $(15,48)$, Kikuchi (46), and Hamada (42). The catalytic performance of the mechanical mixture of $\mathrm{Mn}_{2} \mathrm{O}_{3}$ with $\mathrm{Au} / \mathrm{Al}_{2} \mathrm{O}_{3}$ is at its best in the composition of $\mathrm{Mn}_{2} \mathrm{O}_{3}: \mathrm{Au}(0.2$ wt $\%) / \mathrm{Al}_{2} \mathrm{O}_{3}=1: 19$ in weight and is competitive with that of Pt-MFI [36] in its low-temperature activity. This catalyst gives a negligibly small production of $\mathrm{N}_{2} \mathrm{O}$ and is superior to most of the catalysts reported to be active at high temperatures. It should also be noted that this 


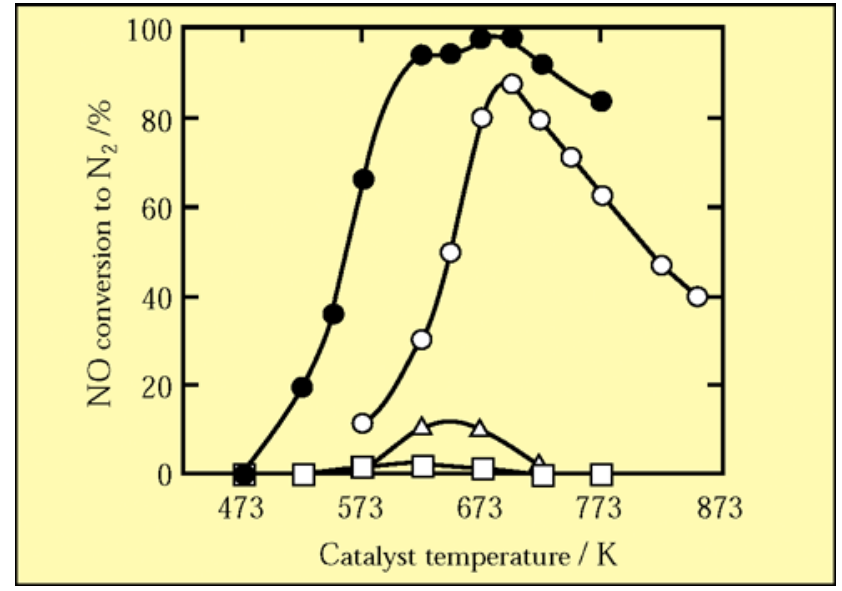

Figure 7 Effect of addition of $\mathrm{Mn}_{2} \mathrm{O}_{3}$ to $\mathrm{Au} / \mathrm{Al}_{2} \mathrm{O}_{3}$ in the reduction of $N O$ with propene. (O), $A u(0.17$ wt.\%) $/ \mathrm{Al}_{2} \mathrm{O}_{3} ;(\triangle), \mathrm{Au}\left(0.16\right.$ wt.\%) $/ \mathrm{Mn}_{2} \mathrm{O}_{3} ;(\square)$, $\mathrm{Mn}_{2} \mathrm{O}_{3}$; (О), $\mathrm{Au}(0.17 \mathrm{wt} \%) / \mathrm{Al}_{2} \mathrm{O}_{3}+\mathrm{Mn}_{2} \mathrm{O}_{3}(19: 1$ in weight). Reaction gas: 0.1 vol\% NO, 0.1 vol\% $\mathrm{C}_{3} \mathrm{H}_{6}, 5 . \mathrm{v}_{\mathrm{vol}} \% \mathrm{O}_{2}$, and $10 . \mathrm{O}_{\mathrm{vol}} \% \mathrm{H}_{2} \mathrm{O}$ in a helium background. Space velocity $=20,000 \mathrm{~h}^{-1}$ $\mathrm{cm}^{3} \mathrm{~g}_{\text {-catalyst }}{ }^{-1}$

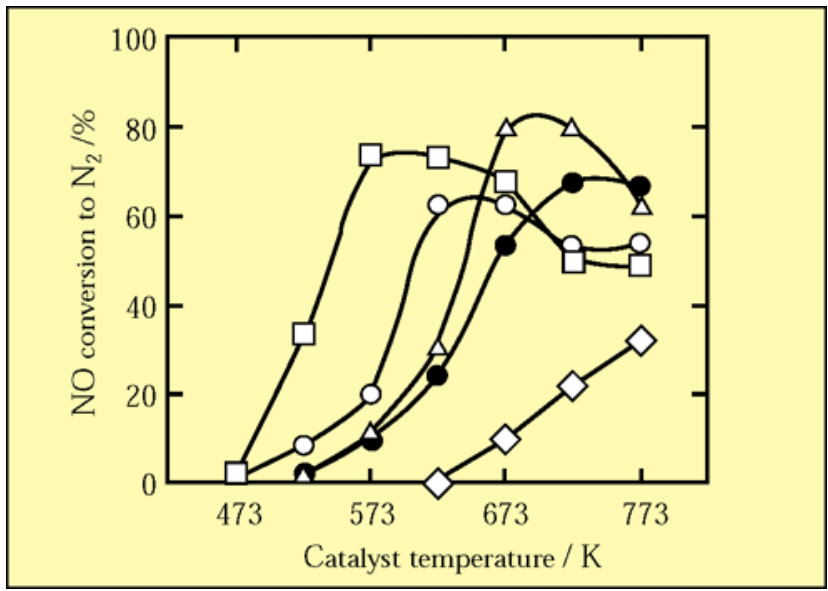

Figure 8 Temperature dependence of $\mathrm{NO}$ conversion to $\mathrm{N}_{2}$ over $\mathrm{Au} / \mathrm{Al}_{2} \mathrm{O}_{3}$ using $\mathrm{C}_{1}-\mathrm{C}_{3}$ hydrocarbons. $(\diamond), \mathrm{CH}_{4}$; (口), $C_{2} H_{4} ;(\bigcirc), C_{2} H_{6} ;(\bigcirc), C_{3} H_{8} ;(\triangle), C_{3} H_{6}$. Gold loading was 0.2 wt\%. Reaction gas; 0.1 vol\% $\mathrm{NO}, 0.1$ vol\% $\mathrm{HC}, 5 . \mathrm{O}_{\mathrm{vol}} \% \mathrm{O}_{2}$, and 10 vol\% $\mathrm{H}_{2} \mathrm{O}$ in a helium background. Space velocity $=20,000 \mathrm{~h}^{-1}$ $\mathrm{cm}^{3}$ g-catalyst $^{-1}$

modified gold catalyst can maintain its catalytic performance under such severe conditions as $20 \mathrm{vol} \%$ oxygen and $10 \mathrm{vol} \%$ water vapour.

Other Hydrocarbons as Reductants

Not only propene, but also ethene, ethane and propane

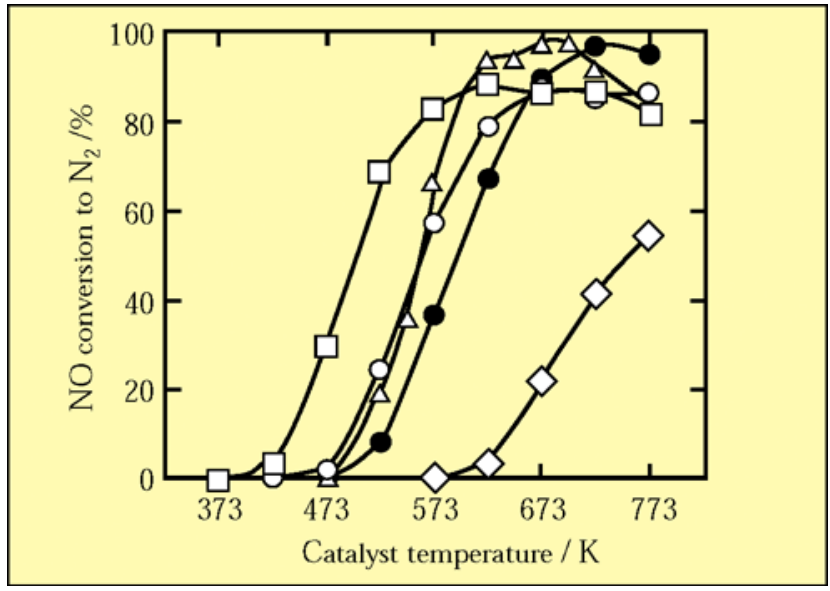

Figure 9 Effect of mechanical mixing $\mathrm{Mn}_{2} \mathrm{O}_{3}$ to $\mathrm{Au} / \mathrm{Al}_{2} \mathrm{O}_{3}$ on the reduction of $N O$ with $C_{1}-C_{3}$ hydrocarbons. $(\diamond)$, $\mathrm{CH}_{4}:(\square), \mathrm{C}_{2} H_{4}:(\mathrm{O}), \mathrm{C}_{2} H_{6}:(\mathrm{O}), \mathrm{C}_{3} H_{8}:(\triangle)$. $\mathrm{C}_{3} \mathrm{H}_{6} \cdot \mathrm{Au}\left(0.17\right.$ wt\%) $/ \mathrm{Al}_{2} \mathrm{O}_{3}: \mathrm{Mn}_{2} \mathrm{O}_{3}=19: 1$ (in weight). Reaction gas; 0.1 vol\% NO. 0.1 vol\% $\mathrm{HC}$, $5.0 \mathrm{vol} \% \mathrm{O}_{2}$, and $10 \mathrm{vol} \% \mathrm{H}_{2} \mathrm{O}$ in a helium background. Space velocity $=20,000 \mathrm{~h}^{-1} \mathrm{~cm}^{3}$ g-catalyst $^{-1}$

can be used as effective reductants for $\mathrm{NO}$ on $\mathrm{Au} / \mathrm{Al}_{2} \mathrm{O}_{3}$ in the presence of oxygen and moisture (47). Figure 8 shows the conversion of $\mathrm{NO}$ to $\mathrm{N}_{2}$ on the $\mathrm{Au} / \mathrm{Al}_{2} \mathrm{O}_{3}$ catalyst as a function of temperature when $\mathrm{C}_{1}-\mathrm{C}_{3}$ hydrocarbons are used as reductants. Ethene shows the highest reactivity for $\mathrm{NO}$ reduction, but methane requires reaction temperatures higher than $623 \mathrm{~K}$. The light-off temperature for the reduction of NO became higher in the following order of hydrocarbons; ethene < ethane < propene, propane < methane. In the case of ethene, as an exception, the direct reaction pathway between $\mathrm{NO}$ and ethene may also take place at temperatures below $523 \mathrm{~K}$ in addition to the route via $\mathrm{NO}_{2}$ as intermediate, because $\mathrm{NO}$ oxidation with $\mathrm{O}_{2}$ over $\mathrm{Au} / \mathrm{Al}_{2} \mathrm{O}_{3}$ is very slow at lower temperatures.

As shown in Figure 9, the mechanical mixing of $\mathrm{Mn}_{2} \mathrm{O}_{3}$ with $\mathrm{Au} / \mathrm{Al}_{2} \mathrm{O}_{3}$ enhances the $\mathrm{NO}$ reduction performance even when other hydrocarbons are used instead of propene.

\section{CONCLUSIONS}

Gold supported on a variety of metal oxides shows good catalytic performance for the reduction of nitric oxide by hydrocarbons such as propene, propane, ethene and ethane. The addition of carbon monoxide 
and hydrogen to the reactant gas can improve the conversion of nitric oxide (NO) to nitrogen. Reaction temperature regions and nitric oxide conversion are widely affected by the selection of metal oxide supports. Zinc oxide support makes gold the most active at low temperatures. Amongst the gold catalysts evaluated, the alumina support showed the highest conversion to nitrogen, but at higher temperatures such as $673 \mathrm{~K}$. Reduction of nitric oxide on gold catalysts is enhanced by the presence of both oxygen $(15 \mathrm{vol} \%)$ and water $(10 \mathrm{vol} \%)$

The reduction of nitric oxide to nitrogen is assumed to take place via the formation of nitrogen dioxide $\left(\mathrm{NO}_{2}\right)$, formed by the oxidation of nitric oxide with oxygen as the first and rate-determining step, and the nitrogen dioxide is then reduced by the hydrocarbon. The mechanical mixture of $\mathrm{Au}_{1} / \mathrm{Al}_{2} \mathrm{O}_{3}$ with $\mathrm{Mn}_{2} \mathrm{O}_{3}$, which is the most active for nitric oxide oxidation, showed appreciably enhanced conversions to nitrogen at temperatures between $523 \mathrm{~K}$ to $773 \mathrm{~K}$. It is not only competitive with Pt-MFI in its lowtemperature activity but is also superior to most of the catalyst materials reported so far at higher temperatures. Although selectivity of propene to nitric oxide reduction against oxygen consumption (hydrocarbon efficiency) is inferior to other metal catalysts, supported gold presents one of the promising catalyst candidates for practical applications for emission control of stationary and road vehicle engines.

Over gold catalysts, the relative order of reactivity is $\mathrm{O}_{2}+\mathrm{CO}>\mathrm{NO}_{2}+\mathrm{CO}>\mathrm{NO}+\mathrm{CO}>\mathrm{O}_{2}+\mathrm{H}_{2}>$ $\mathrm{NO}_{2}+\mathrm{H}_{2}>\mathrm{NO}+\mathrm{O}_{2}>\mathrm{NO}_{2}+\mathrm{C}_{3} \mathrm{H}_{6}>\mathrm{O}_{2}+\mathrm{C}_{2} \mathrm{H}_{6}>$ $\mathrm{NO}+\mathrm{C}_{3} \mathrm{H}_{6}$. The combination of $\mathrm{NO}$ oxidation to $\mathrm{NO}_{2}$ and $\mathrm{NO}_{2}$ reduction by reducing gases such as carbon monoxide, hydrogen, and hydrocarbons should be taken into account when seeking further improvements in the performance of gold-based catalysts.

\section{ABOUT THE AUTHORS}

Dr Masatake Haruta is the Chief Senior Researcher and Head of the Interdisciplinary Basic Research Section at the Osaka National Institute, AIST, Japan. His principal research field is novel catalysis using gold deposited on metal oxides. Mr Atsushi Ueda is a Senior Researcher, Catalysis Section, Department of Energy and the Environment at the same Institute, and his research is concerned with studying the surface properties of finely dispersed materials for use as catalysts in energy-related and environmental applications.

\section{REFERENCES}

1 M. Haruta, T. Kobayashi, H. Sano and N. Yamada, Chem. Lett, 1987, 405

2 M. Haruta, N. Yamada, T. Kobayashi and S. Iijima, J. Catal., 1989, 115, 301

3 M. Haruta, Catalysis Surveys of Japan, 1997, 1,61

4 M. Haruta, Catal. Today, 1997, 36, 153

5 J. S. Summers, J. E. Sawyer and A. C. Frost, in 'Catalytic Control of Air Pollution: Mobile and Stationary Sources', ed. R. G. Silver, J. E. Sawyer and J. C. Summers, ACS Symp. Series, Washington, 1991, 495, 98

6 R. M. Heck and R. J. Farrauto, in 'Catalytic Air Pollution Control - Commercial Technology', Van Nostrand Reinhold, Berlin, 1995, p. 161

7 P. Zelenka, W. Cartellieri and P. Herzog, Appl. Catal. B, 1996, 10, 3

8 W. Held, A. Koenig, T. Richter and L. Puppe, Society of Automobile Engineers, Technical Paper Series 900496, 1990

9 H.K. Shin, H. Hirabayashi, H. Yahiro, M. Watanabe and M. Iwamoto, Catal. Today, 1995, 26, 13

10 M. Iwamoto, H. Yahiro, S Shundo, Y. Yu-u and N. Mizuno, Appl. Catal, 1991, 69, L15

11 T. Inui, S. Iwamoto, S. Koji and T. Yoshida, Catal. Lett., 1992, 13, 87

12 T. Tabata, M. Kokitsu, O. Okada, T. Nakayama, T. Yasumatsu and H. Sakane, in 'Catalyst Deactivation 1994 (Studies in Surface Science and Catalysis)', ed. B. Delmon and G. F. Froment, Elsevier, Amsterdam, 1994, 88, 409

13 Y. Li and J. N. Armor, Appl. Catal. B, 1992, 1, L31

14 E. Kikuchi, M. Ogura, N. Aratani, Y. Sugiura, S. Hiromoto and K. Yogo, Catal. Today, $1996,27,35$

15 C. Yokoyama and M. Misono, J. Catal, 1994, 150,9

16 H. Ohtsuka, T. Tabata, O. Okada, L.M.F. Sabatino and G. Bellussi, Catal. Lett, 1997, 44, 265

17 S. Tsubota, D.A.H. Cunningham, Y. Bando and M. Haruta, in 'Preparation of Catalysts VI, ed. G. Poncelet et al, Elsevier, Amsterdam,1995, p. 227

18 A. Ueda and M. Haruta, Appl. Catal. B, 1998, 18, 115

19 K.C. Taylor, in 'Catalysis: Science and Technology', ed. J.R. Anderson and M. Boudart, Springer-Verlag, Berlin, 1984, 5, 119

20 K.C. Taylor, Catal. Rev. - Sci. Eng, 1993, 35, 457

21 T.P. Kobylinsky and B.W. Taylor, J. Catal, 1974, 33, 376

22 H. Murakami and Y. Fujitani, Ind. Fng. Chem. Prod. Res. Dev, 1986, 25, 414

23 H. Shinjoh, H. Murakami and Y. Fujitani, in 'Studies in Surface Science and Catalysis', ed. A. Crucq and A. Frennet, Elsevier, Amsterdam 1987, 30, 187

24 K.C. Taylor and J.C. Schlatter, J. Catal, 1980, 63, 53

25 B. Harrison, A.F. Diwell and C. Hallet, Platinum Metals Rev, 1988, 32, 73

26 J. Barbier, C. Micheaud, E. Rohart and E. Lafitte, in 'Catalysis by Metals, ed. A.J. Renouprez and H. Jobic, Springer-Verlag, Berlin,1997, p.133

27 F. Boccuzi, A. Chiorino, S. Tsubota and M. Haruta, J. Phys. Chem., 1997, 100, 3625

28 J.M. Schwartz and L.D. Schmidt, J. Catal., 1994, 148, 22

29 M. Skoglundh, A. Torncrona, P. Thormahlen, E. Fridell, A. Drewsen and E. Jobson, in 'Studies in Surface Science and Catalysis', ed. N. Kruse, A. Frennet and J.-M Bastin, Elsevier Science B.V., Amsterdam, 1998, 116, 116

30 J.F. Trillat, J. Massuadier, B. Moraweck, H. Praliaud and A.J. Renouprez, in 'Studies in Surface Science and Catalysis', ed. M. Kruse, A. Frennet and J.-M Bastin, Elsevier Science B.V., Amsterdam, 1998, 116, 103

31 A.El Hamdaoui, G. Bergeret, J. Massardier, M. Primet and A. Renouprez, J. Catal. $1994,148,47$

Continued on page 23 